\title{
How Social Transformation Is Affecting Female Clothing Change in the Late Qing Dynasty and the Early Republic of China
}

\author{
Xuefei Zhang ${ }^{1} \&$ Xiaoming Yang ${ }^{1}$ \\ ${ }^{1}$ College of Humanities, Donghua University, Changning, Shanghai, P.R. China \\ Correspondence: Xiaoming Yang, College of Humanities, Donghua University, Changning, Shanghai, 200051, \\ P.R. China. E-mail: ynide@ sina.com
}

Received: August 23, 2020

doi:10.5539/ass.v16n10p53
Online Published: September 24, 2020

URL: https://doi.org/10.5539/ass.v16n10p53

Supported by the Fundamental Research Funds for the Central Universities and Graduate student Innovation Funds of Donghua University (Grant No. CUSF-DH-D-2019104).

\begin{abstract}
During the late Qing dynasty and the early Republic of China, women's clothing had a revolutionary change. Under the unprecedented social transformation in a millennium, Social Darwinism called for "mother of the citizens", arousing public concern to release women's bodies. Anti-foot-binding movement awakened women's self-awareness and planted a hint of women's emancipation. While Feminism turned the value to the "parity of citizens," women disguised their female character and dressed as men. Early Qipao was widespread during women's liberation movement. The New Culture Movement facilitated ideology of Human Liberation. Women gradually possessed independence of personality and changed their corsets. They tended to confront and express body curves instead of cover and weakening.
\end{abstract}

Keywords: the late Qing dynasty, the early Republic of China, women, clothing change, social transformation, social psychology

\section{Background}

The social transformation in the late Qing and the early Republic took place under the background of the national revival and women's liberation. From the failure of the Reform Movement of 1898, the elites have realized that top-down reformation was not feasible, and that strengthening the people was on priority basis. The emancipation of women's body was included in the evolutionary context of "strengthening the nation and strengthening the species" and traditional women's clothing was considered as a hindrance to the growth of the "mother of the citizens". "one's dressing is as vital as one's political regime", therefore social change must took thoroughly, so did clothing change. It was imperative to abolish the feudal system and obsolete traditional ideas that civilization was distinguished by dressing. The Revolution of 1911 had overthrown a thousand years of monarchy, but republican democracy was not achieved. National revival remained the most essential task in this period. After the May Fourth Movement, women's emancipation has become a hot issue in intellectual class, arousing great concern in society, and women gradually possessed independent personalities. The dramatic changes in dressing reflected the changes of modern women both in appearance and thinking ways, which became witnesses of women's emancipation.

In ancient China, women's clothing was not significant but restrictive. As the old saying goes, "The woman's wear follows her husband". The reformation of clothing system was usually accompanied by political power change. When the Qing dynasty was built, it was imperative rule that male clothing must change but female does not. In traditional culture, "An ideal Chinese woman" was small and slim covered by loads of clothes. The over-decorated garments made by silk and embroidery seem like ropes, binding women's body and mind tightly. The feudal social order including hierarchy of clothing, remained stable despite the change of dynasties. At the turn of Late Qing Dynasty and Republican periods, the ritual collapsed, and clothing broke its rules. Civil rights revolution and the struggle for human rights were complicated, thus there were dramatic changes in dress that deviated from traditional patterns. In a society where the hierarchical ethics were aberrant, the silent dress spoke out, and changing dress behavior became an effective way for women to express their attitudes and demands 
directly, more powerfully than in words, more vividly than in writing. This was an era of change. Women dressed in different ways, including menswear, new civilized outfit, Manchu's wear and western dress.

\section{The Relationship Between Social Transformation, Social Trends and Social Psychology}

Some Western scholars have illustrated that the effects of social movements and social trends should be taken into account when considering clothing behavior as a research object. Once examining dressing behavior through social change, the psychosocial process can be perceived (Kaiser, 2000). Thus, it is vital to introduce the concepts of social trends and social psychology when examining how social transformation is affect clothing changes. The end of the Qing dynasty confronted the unprecedented change of the millennium: "Chinese garments, which used to represent splendid civilization were despised of foreigners" (Anonymous, 1928). The society was turbulent, and the nation was in need of revival. The intellectuals had to shift their mindset from "distinguishing of the barbarians' tribes and China" to "China has been left behind" (Chen, 1904). With the aspiration to achieve national revival, elites attempted to seek methods from Western ideological trends (Liang, 1908). Social Darwinism advocated competition and national evolution instead of traditional Yixia conception, which made a great impact in Chinese society. Feminism was emerged under the West influence and the evolution of the citizens. Female elites of the Qing dynasty called for women to participate in social revolution and contribute to the nation.

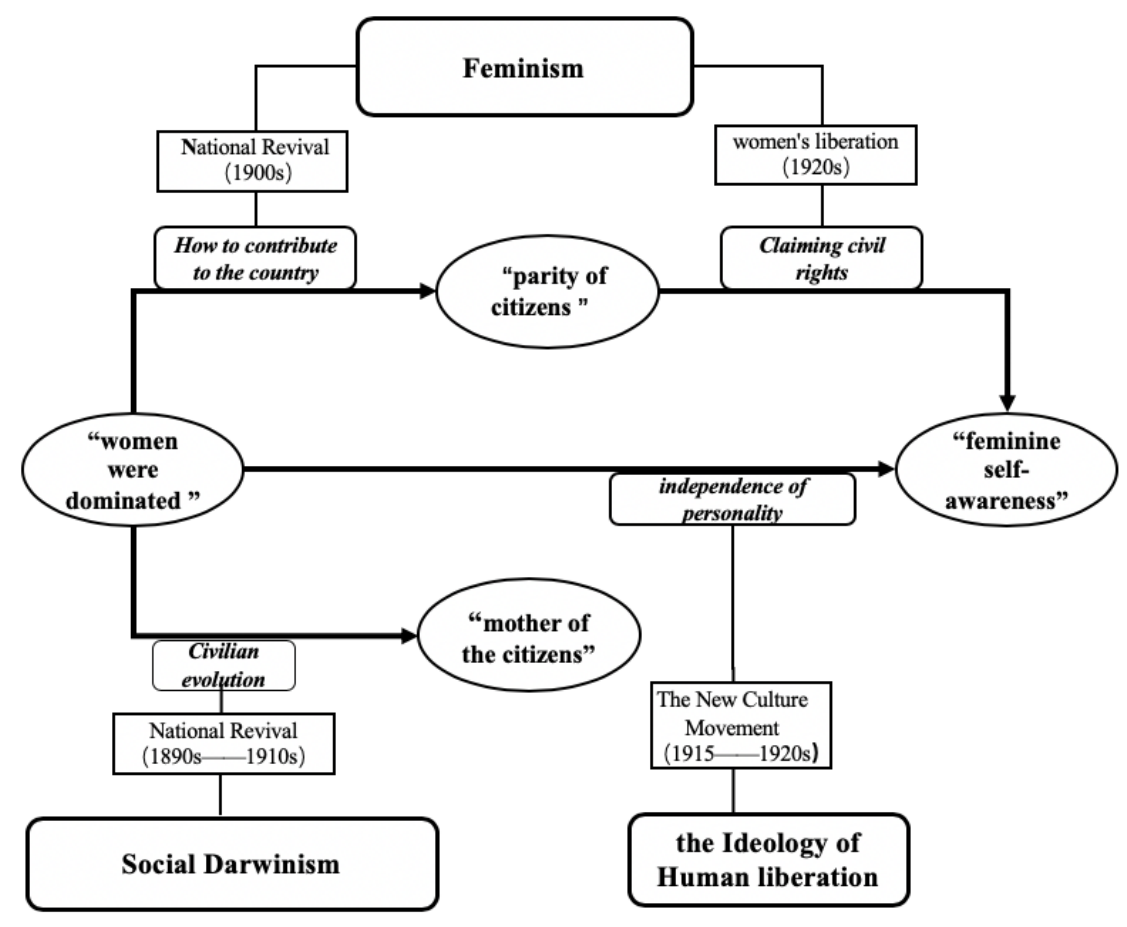

Figure 1. The relationship between social trends, social transformation and social psychology

During the social changes, the themes of the times tended to be diversified and complicated. Then social trends have undertaken transformations to a great extent: during the Hundred Days' of Reform and 1911 revolution, national revival was the top priority, Social Darwinism dominated the intellectual world. All social issues concerning people were elucidated in the context of civilian evolution. During the period of the New Culture Movement, human beings, as social subjects, received excessive attention. Intellectuals recognized that social evolution must presuppose individual's emancipation (Chen, 1988). Women's liberation had been raised as a crucial social issue, and the theme of Feminism turned from "how to contribute to the country" to "claiming civil rights" (Mizuyo Sudo, 2010). The New Culture Movement was deeply influenced by Western civilization and was an ideological revolution, which could be regarded as the Enlightenment in China. Chen (1916), a pioneer of the New Culture Movement, pointed out: "equality of human rights legally, independence of personality ethically and elimination of superstition academically are the fundamental reasons for the evolution of western civilizations". In this paper, we have chosen "independence of personality ethically "as the basis of our discussion since it was highly connected with individuals and clothing change. In this case, social claims 
concerning people could be regarded as "the ideology of Human Liberation". According to Wang (1997), social trend is dominated by theoretical ideas and involved with the psychological factors of the general public. The reason for the prevalent of two major ideological trends, Social Darwinism and Feminism, was inseparable with the social psychology of women who wanted to be emancipated. The female social psychology focused on how individuals in general view female issues and affect one another. According to the historical transition of social trends, the social psychology of women could be divided into four stages: women were dominated, mother of the citizens, parity of the citizens and feminine self-awareness. In the context of Social Darwinism, national revival has become the mainstream consensus. Such values that women should take reproductive responsibility has been advocated. Women must be strong, bringing up strong citizens in order to contribute to prosperous country. At the beginning of the 20th century, Zeng (1904) said, women were like prisoners and were not allowed to step over the line. She pointed out that women are not only mother of the citizens but also parity of the citizens. If women do not aware of their civil rights but only fulfill their responsibilities, then there will be no self-reliant women, no self-reliant citizens, and no possibilities of national revival. Qiu (1979) further elaborated feminism that both men and women possess equal right which is natural right. Female citizens' right is unalienable. During the New Culture Movement, the proposal about Feminism is more explicit as women demanded political right including suffrage. The ideology of human liberation suggests that women has independent personalities and should be self-reliant in society (Shaoxian, 1921). By the time of 1920s, some female elites drive to build the image of feminine self-awareness. However, it remained as a few individuals' aspirations, not firmly achieved in general social psychologically (see Figure 1).

\section{Social Transformation Affecting on Chinese Female Clothing Change}

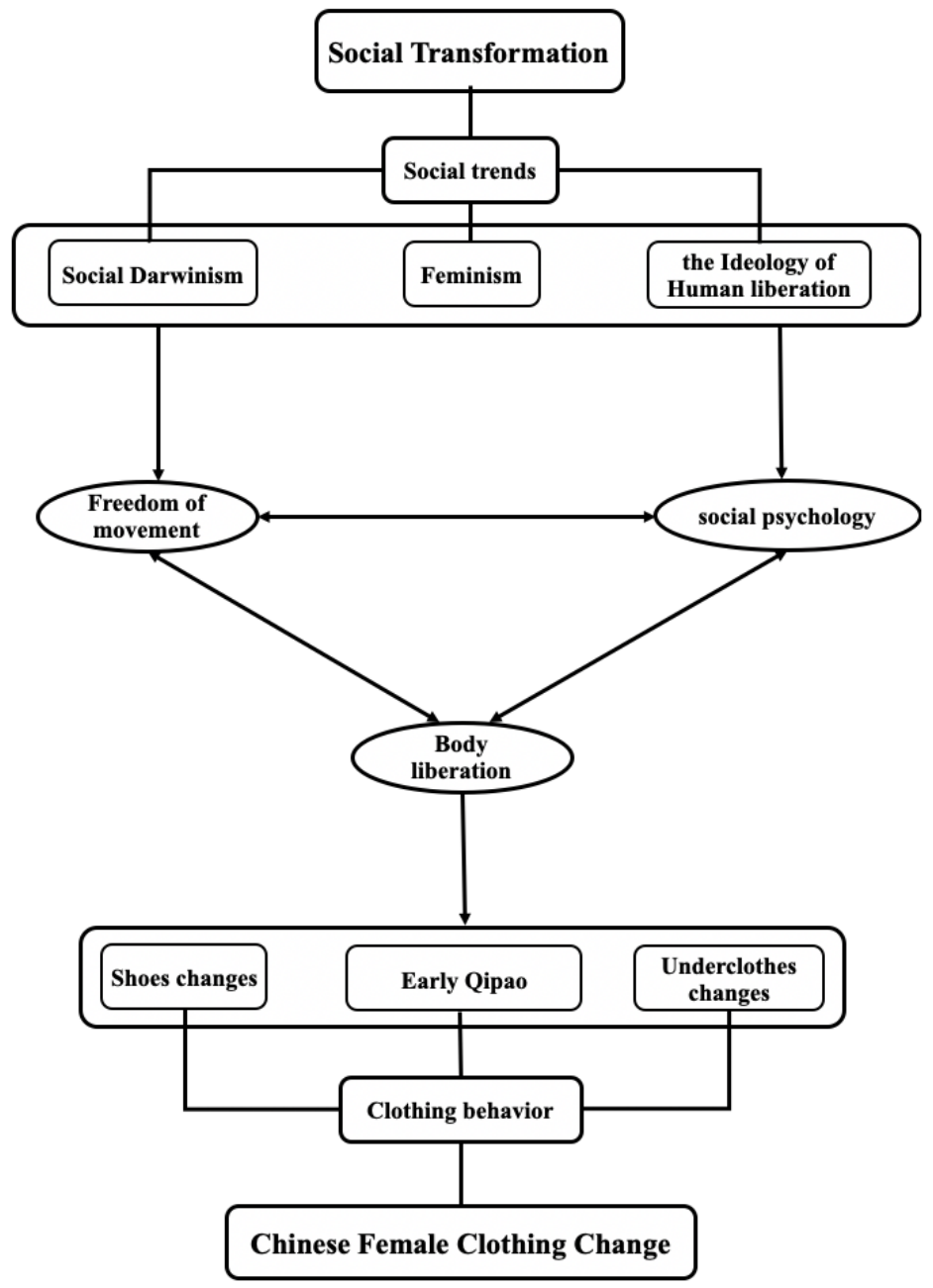

Figure 2. Social Transformation affecting on Chinese Female Clothing Change 
Social behavior depends on how people construct their subjectivity as underlying social psychology (Myers, 2006). The social psychology of modern women has influenced on the choice of dressing to a great extent. In the olden days, women were dominated by men and served their families, so they had to bind their feet to fit three-inches shoes. When women were called upon to fulfill their responsibilities as mothers under national evolutionary context, three-inches shoes were no longer suitable for their released feet. Thus, footwear that fit to human body has emerged complying with requirements. When women asserted their civil right as equal as man, they tended to play male-like roles by dressing de-gendering clothes.

In summary, women's clothing change began with the change of footwear. During the Hundred Years' Reform period, the traditional scholars promoted the anti-foot-binding Movement, and in the early Republican period, the government strictly abolish foot-binding. Under the profound influence of the national evolutionary ideology advocated by Social Darwinism, women's reproductive role as the mother of the citizens was especially emphasized, and the right to education was widely proposed. In the 1920s, Early Qipao which embodied masculinity, was prevalent among the feminine world. At the end of the 1920s, women's breast was released from corset vest. cheongsams and underclothes tended to confront and express body curves instead of cover and weakening. Inspired by the ideology of human liberation, women began to pursue independent personality, and famine self-awareness initially emerged. In this process, body liberation, freedom of movement and social psychology interacted with each other, becoming the intermediate variables and central force in the impact of social transformation on clothing change (See Figure 2).

\section{References}

Anonymous. (1928, October 10). Declaration and Constitution of the Xingzhonghui. Jian Guo (Guangzhou), 21-22 joint editions, 27-28.

Chen, D. X. (1916, December 1). The Resurrection of Yuan Shikai. New Youth, 2(4), 22-24.

Chen, T. S. (1988, October 27). Emancipation and Sublimation: Reflections on the Emancipation of Humanity in the New Thought during the May Fourth Movement. Social Science Research, 5, 83-88.

Chen, W. (1904, June 5). On the Disadvantages of Wedding. Jue Min, 1-5 joint editions, 30-40.

Kaiser, S. B. (1985/2000). The social psychology of clothing (Li, H.W. Trans.). Beijing: China Textile Publishing House.

Liang, Q. C. (1908). An introduction to the study of the Qing dynasty. Shanghai: Shanghai Ancient Books Publishing House.

Myers, D. G. (2001/2019). Social psychology (11th ed.) (Hu, Y. B., Le, G. P., \& Zhang, Z. Y. Trans.). Beijing: People's Post and Telegraph Publishing House.

Qiu, J. (1979). Qiu jin. Shanghai: Shanghai Ancient Books Publishing House.

Shaoxian. (1921, November). My Views on the Equality of Men and Women in Personality. Women's Journal, 7(11), 109-110.

Sudo, M. (2007/2010). Changes in the Concept of Women's Rights in China - Human rights and gender in the late Qing dynasty and early Republic of China (Mizuyo Sudo \& Yao, Y. Trans.). Beijing: Chinese Social Science Literature Publishing House.

Wang, J. Z. (1997, March 15). The Origin, Function and Development Trend of Social Trends. Qi Lu Journal, 2 , 56-60.

Zeng, J. X. (1904, April 16). Women's rights as the key to a strong nation. Women's World, 3, 79-80.

\section{Copyrights}

Copyright for this article is retained by the author(s), with first publication rights granted to the journal.

This is an open-access article distributed under the terms and conditions of the Creative Commons Attribution license (http://creativecommons.org/licenses/by/4.0/). 